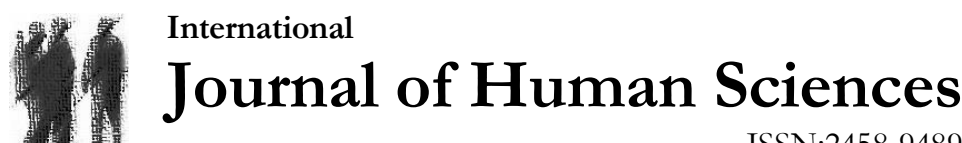 \\ ISSN:2458-9489
}

Volume: 18 Issue: 2 Year: 2021

\section{Assessment of urban development pattern and urban sprawl using Shannon's entropy: A case study of Konya (Turkey)}

\author{
Neslihan Serdaroğlu Sağ
}

\begin{abstract}
Defined as the uncontrolled expansion of cities toward their periphery, urban sprawl emerges during urban developments where the urban area grows more than the population increase. Furthermore, land-related demands emerge for the needs regarding settlement and infrastructure due to certain reasons such as the increase in the urban population, industrialization and lifestyle changes. As these demands are met through irregular area use, cities expand toward their peripheral areas more than necessary. Moreover, natural resources and agricultural areas are damaged, infrastructure and transportation costs increase, urban functions get separated, and social and financial issues occur. The problem of urban sprawl is one of the major issues suffered by the global cities in the last decades. For Turkey where approximately $75 \%$ of the population live in cities, examining the urban developments and specifying the rate of urban sprawl is critical. This study aimed to assess the case study of urban development and sprawl in Konya (Turkey). It first examined the population and urban area in the urban plans guiding the urban development pattern. Then, the study analyzed the changes the built-up areas underwent for 35 years between 1985 and 2020. As method, satellite images and GIS were used. Moreover, the level of sprawl regarding the urban development in Konya was measured based on Shannon's Entropy Index. Finally, this study found that Konya was suffering the issue of sprawl, and it emphasized the importance of studies for guiding the activities of urban development in a sustainable manner.
\end{abstract}

Keywords: Urban sprawl; urban planning; urban development; Shannon's entropy; Konya.

\section{Introduction}

The global urban growth $(80 \%)$ in the last 30 years significantly exceeded the rate of providing urban areas for compensating the demands related to population growth (52\%) (Liu et al., 2020). In the current period, $75 \%$ of population in Turkey (WEB1) as well as approximately $73 \%$ of the European population and more than $55 \%$ of the global population live in cities. The global rate is expected to reach 68\% by 2050 (UN, 2019; WEB2). The need for lands around the cities has reached to a significant degree. Rapid changes occur in the use of lands every day, affecting the cities and natural environments around the cities. Newly urbanized areas started to put pressure on natural areas such as agricultural lands (70\%) and forests (9\%) (Liu et al., 2020). Turkey's rural areas consisted

\footnotetext{
${ }^{1}$ Assist. Prof. Dr., Konya Technical University, Faculty of Architecture and Design, Department of Urban and Regional Planning,nssag@ktun.edu.tr (iD) Orcid ID: 0000-0001-8002-4499
} 
Serdaroğlu Sağ, N. (2021). Assessment of urban development pattern and urban sprawl using Shannon's entropy: A case study of Konya (Turkey). Journal of Human Sciences, 18(2), 252-265. doi:10.14687/jhs.v18i2.6158

of agricultural areas (36.1\%) in 1988, but these areas covered more smaller percent $(30.8 \%)$ in 2016. Agricultural areas covering approximately 40 million acres was abandoned to housing in the last 30 years (WEB3). As people's demand for settlement areas and infrastructures increase, cities expand and sprawl toward their environments more than necessary. Urban sprawl emerges in cases where the transformation of land use and urban consumption rates exceed the population increase in a certain location at a certain time (EEA Breafing, 2006). Traces of urban sprawl are defined as the increase in the rate of vehicle use, separation in land uses, losses in agricultural lands, (Burchell et al., 2000; Glaeser \& Kahn, 2004), loss of biological diversity (Alberti, 2005), increase in environmental pollution (Sierra Club, 1998), and social and economic segregation (Sierra Club, 1998; Burchell et al., 2000; Glaeser \& Kahn, 2004). As these issues emerge in a certain location, it becomes obligatory for local authorities to create policies to prevent the urban sprawl (Serdaroğlu Sağ, 2011).

Urban sprawl commonly considered as a problem by local goverments today (EEA Breafing, 2006). Therefore, the studies on specifying the trends of urban growth and changes create a highly significant agenda for determining the current problems and potential needs of a certain area in the context of preventing and mitigating urban sprawl. This study aimed to assess the cases of urban development and sprawl in Konya, the seventh largest metropolis in Turkey as population (provincial population: 2,250,020; central population: 1,352,879) Konya is the city with the largest municipal boundary in Turkey, and the city is accepted as the agricultural region (Url-4). Konya is under an intense population-related pressure as it has a central location and is among Turkey's developed metropolis in certain fields such as agriculture, transportation, industry, education and health. A total of 17,629 ha productive agricultural lands have been lost in the last 50 years due to urbanization and needs of urban development (Akseki \& Meşhur, 2013), and the city expanded toward the productive agricultural lands in the south (Karakayac1 \& Karakayac1, 2019). Moreover, urban area of Konya reached $30 \mathrm{~km}$ from the north to south and $15 \mathrm{~km}$ from the east to west (Yavuz, 2021) which makes the topic of urban sprawl - an important topic of discussion in the entire globe-also critical for Konya considering the loss of agricultural areas.

Determining the physical aspects (the rate and level) of the urban sprawl in Konya through quantitative methods will contribute to the efforts of planning and shed light on the discussions of how the urban development may occur in future and what sorts of measures can be taken against urban sprawl. The main question of this article is what is the sprawl level of Konya city? Accordingly, the literature was reviewed in terms of the topics of urban sprawl, urban sprawl indicators and measurement of urban sprawl. Then, the level of urban sprawl in Konya was assessed through the degree of dispersion regarding the urban development pattern. The points to be considered in the planning efforts were mentioned based on the urban sprawl level.

\section{Urban sprawl, indicators and measurement of urban sprawl}

The issue of urban sprawl is commonly examined particularly in Europe and United States where the developed urban area have grown much faster than the population increase (EEA Report 2006). Urban sprawl is generally defined as an uncontrolled and (Resnik, 2010) unplanned (EEA Report, 2006; Kumari, 2015; Terzi \& Bölen, 2010) process.

Factors such as population growth, development of transportation and communication infrastructure, increase in vehicle ownership, better economic development and lifestyle are reflected as the reasons of urban sprawl (Ewing, 1997; Galster et al., 2001).

With an approach originating from North America, the urban sprawl is defined as follows: "a new development that surrounds an urban area, that has low density, that is vehicle dependent and that is disconnected from the urban settlement, indicating a leapfrog development" (Buitelaar \& Leinfelder cited by Squires, 2002). European Environment Agency (EEA) defines urban areas as the physical model of the development that has low density and that is irregular, disorganized and discontinuous within agricultural areas (Buitelaar \& Leinfelder, 2020).

Urban sprawl indicates the degree of construction regarding an urban area as well as the size of the sprawl in the urban environment. The more buildings and urban areas cover a specific surface 
Serdaroğlu Sağ, N. (2021). Assessment of urban development pattern and urban sprawl using Shannon's entropy: A case study of Konya (Turkey). Journal of Human Sciences, 18(2), 252-265. doi:10.14687/jhs.v18i2.6158

area and the more disorganized the development is, the higher the level of urban sprawl becomes. (Buitelaar \& Leinfelder, 2020; Mohammadi et al., 2012; Sarvestani et al., 2011). Main characteristics of sprawl include out-of-service areas in the built-up areas and scattered development, development in low-density housing zones, leapfrog development on important axes, strip development, and finally, low accessibility (Ewing, 1997; Galster et al., 2001; Torrens \& Alberti, 2000).

In recent years, different studies have been presented in the literature regarding the definition of urban sprawl. While describing the phenomenon, there are opinions that causes and consequences cause confusion. For example, poor accessibility, vehicle dependency or environmental impacts are the result of sprawl, and are often included in its definition.

At this point, definitions that reveal the main characteristics of urban sprawl have been developed. As revealed in recent studies, urban sprawl; It is a form of urban growth characterized by low population density, decentralized and leap-frog development (OECD, 2018).

Usually, the literature about urban sprawl refers to the high spatial growth in cities. The studies on urban sprawl in the literature review the measurement of the sprawl, determining the parameters, (Ashkenazi, 2008; Çavuş \& Başaran Uysal, 2018; Ewing et al., 2002; Frenkel \& Ashkenazi, 2008; Galster et al., 2001; Hasse \& Lathrop, 2003; Öztürk, 2017 a-b; Yeh \& Li, 2001; Shenbagaraj et al., 2019; Sudhira et al., 2004); reasons and impacts regarding the measurements, and (potential) policy measures, (Buitelaar \& Leinfelder, 2020; Ewing, 1997; Ewing et al., 2002; Galster et al., 2001; Torrens \&Alberti, 2000) or a combination of these. These studies generally produced different sprawl indexes and were conducted in this regard (Frenkel \& Ashkenazi, 2008; Galster et al., 2001). These indexes are specified by the parameters related to income, demography, land use, agricultural land value, transportation, and socio-economic, climatic and geo-physical elements (Buitelaar \& Leinfelder, 2020; Ewing et al., 2002).

Galster et al. (2001) utilized eight parameters, which are density, continuity, concentration, clustering, centrality, nuclearization, mixed use and proximity, to determine the level of urban sprawl. Ewing et al. (2002) used four parameters as sprawl index, which are the density of housing zones, mixed land use, attraction of sub-centers and accessibility. Hasse and Lathrop (2003) considered the changes in natural areas such as wetlands, forests or productive agricultural lands among the parameters of urban sprawl measurement. Indicators of population and density are among the parameters used in the measurement of urban sprawl (Burton, 2000; Çavuş \& Başaran Uysal 2018; Ghorbani\& Farokhisomeh, 2015; Pendall, 1999; Steurer \& Bayr, 2020; Yeh \& Li, 2001). Macroform and size are among the other parameters accepted to prevent urban sprawl (Torrens \& Alberti, 2000; Sudhira et al., 2004).

As understood from the assessment of these studies, the most commonly used parameters of measuring urban sprawl are population, population increase, density, settlement area form and size, accessibility, mixed land use, centrality and continuity. Assessments regarding the concept of urban sprawl were performed through the parameters of population, population growth, density and builtup area size.

Considering the fact that urban development is an inevitable process, planned guiding efforts which will ensure the development/settlement will conserve the natural resources and meet people's needs should be developed.

Therefore, the topic of monitoring urban expansion and settlement catches more attention (Shenbagaraj et al., 2019). Studies on measuring the stylistic characteristic of sprawl and assessing the urban development have accelerated in recent years (Öztürk, 2017 a-b; Shenbagaraj et al., 2019; Terzi \& Bölen, 2010). In addition to qualitative assessments, quantitative examinations and mathematical and mixed fuzzy analysis methods are commonly used to measure the urban and stylistic characteristics.

Accordingly, shape index as well as contagion index, Shannon's entropy index (Bhatta, 2012; Öztürk, 2017 a-b; Shenbagaraj et al., 2019 cited by Garg \& Sharma, 2018; Sudhira et al., 2004; Yeh \& Li, 2001), Holderness method (Mohammadi et al., 2012; Ghorbani \& Farokhisomeh, 2015) 
Serdaroğlu Sağ, N. (2021). Assessment of urban development pattern and urban sprawl using Shannon's entropy: A case study of Konya (Turkey). Journal of Human Sciences, 18(2), 252-265. doi:10.14687/jhs.v18i2.6158

Geographical Information System (GIS) and fractal analysis have captured great attention in the studies on urban sprawl (Bhatta, 2012; Öztürk, 2017 a-b; Shenbagaraj et al., 2019 cited by Garg \& Sharma, 2018; Steurer \& Bayr, 2020; Sudhira et al., 2004; Terzi \& Bölen, 2010; Yeh \& Li, 2001).

Based on the data collected from the literature, this study revealed the case of urban sprawl in Konya using Shannon's entropy (Shannon, 1948) and the degree of dispersion of urban development. The details in this regard were mentioned in the methods section.

\section{Method and material}

This applied study was conducted with both qualitative and quantitative methods. Materials of the study included the plans regarding Konya, plan reports, statistical data regarding population and urban area, Google Earth satellite images from 1985, 2000, 2010 and 2020, and the data collected from articles, books and theses. The afore-noted materials were obtained from certain institutions such as Metropolitan Municipality of Konya, Ministry of Environment and Urbanization, and Turkish Statistical Institute (TUIK), and from libraries, online databases and scans.

The study is based on three basic analyses. In the first one, plans made between 1946 and 2018 and urban development process were assessed briefly. In the second analysis, urban development pattern covering 35 years between 1985 and 2020 was assessed. The size of built-up areas in central locations of Konya was calculated by digitalizing the Google Earth satellite images from 1985, 1990, 2000, 2010 and 2020 on GIS. The reason of these years to be selected was that assessments were performed for the 1983 plan, the first comprehensive plan of the city, and for the following periods. Furthermore, efforts were made to determine the level of urban sprawl. The annual data obtained from TUIK for the urban population of the metropolitan area in Konya were used within the quantitative assessments for determining the urban sprawl level.

The sprawl level of urban development was calculated using Shannon's entropy, one of the most common and reliable methods used to determine the urban area dynamics and urban sprawl (Öztürk, 2017 a-b; Sarvestani vet al., 2011; Sudhira et al., 2004; Yeh \& Li, 2001).

To understand the urban growth better, built-up area is calculated for every period reviewed (Shenbagaraj et al., 2019). Shannon's entropy is used to measure the spatial concentration or dispersion degree of geographical variables within " $n$ " spatial units / areas. Entropy values indicate the level of urban sprawl by examining the compactness and sprawl of an urban development within urban studies (Jat et al., 2008; Öztürk, 2017 a-b).

General structure of Shannon's entropy (1948) is as follows:

$\mathrm{H}=-\Sigma \mathrm{ni}=1 \mathrm{Pi} \times \operatorname{Ln}(\mathrm{Pi})$

$\mathrm{H}$ is the value of Shannon's entropy. Pi indicates the ratio of built-up area to the total of areas, while $\mathrm{n}$ is the total number of areas. $\mathrm{Ln}(\mathrm{n})$ shows the physical growth of cities. The entropy value is calculated by dividing the number of built-up areas in every pre-determined region into the total number of built-up areas (Öztürk, 2017 a-b; Sun et al., 2007; Yeh \& Li, 2001).

Based on the results obtained from the three analyses mentioned above, urban development of Konya was evaluated, and the dimensions of urban sprawl were discussed.

\section{Results of the case of Konya}

\subsection{Planning process and urban development of Konya}

Considered as one of the oldest settlements in Anatolia, Konya is located on the central parts of Turkey (Figure 1). Its boundaries covers 4,083,800 ha, 1,876,344 ha of which serves for agricultural purposes. The agricultural area in Konya consists of $8.12 \%$ of the agricultural land in Turkey (Konya Chamber of Commerce, 2020). 
Serdaroğlu Sağ, N. (2021). Assessment of urban development pattern and urban sprawl using Shannon's entropy: A case study of Konya (Turkey). Journal of Human Sciences, 18(2), 252-265. doi:10.14687/jhs.v18i2.6158

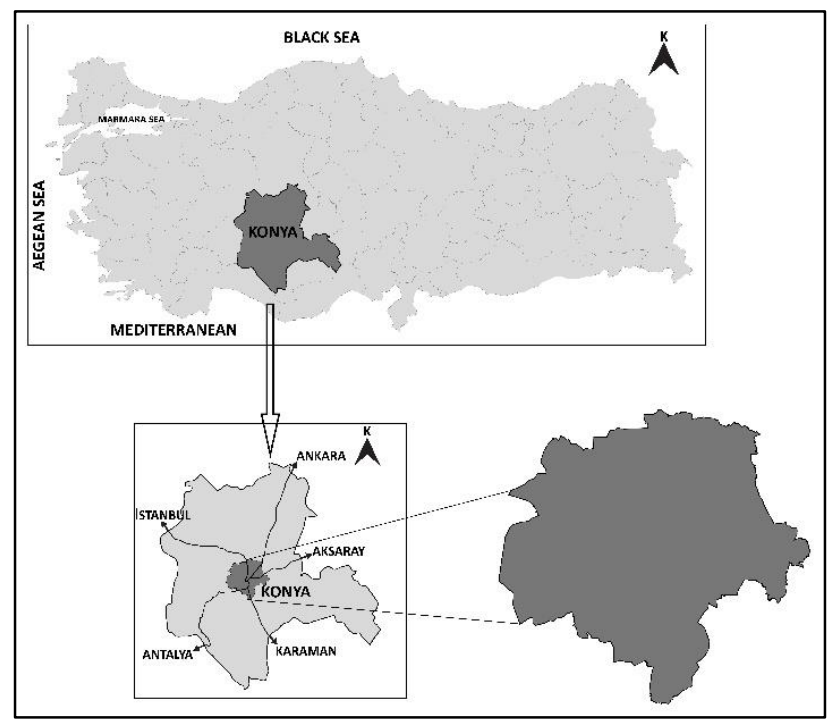

Figure 1. Location of the Konya

Konya is one of the major Turkish cities in terms of agricultural production, trade, employment and industry sectors. The city is located on a flat land with a productive plain. Due to the absence of a distinctive natural line that borders the city, Konya covers a large area. A significant part of the productive lands around the city has been urbanized. The spatial decisions and policies within the plans of Konya urban center were not examined in detail within the assessment of urban development and growth of the city. The relationship between the plans and urban development was assessed based on the general data regarding the target year within the plans, projection population, size of the planning area, density-related decisions and the direction of the development (Table 1).

Table 1. General data regarding the plans for Konya (updated by the author after citation from Akseki \& Meşhur, 2013 and Yenice, 2012)

\begin{tabular}{|c|c|c|c|c|c|}
\hline Planning data & 1946 Plan & 1966 Plan & $\begin{array}{l}1983 \text { Master } \\
\text { Plan }\end{array}$ & $\begin{array}{l}1999 \text { Master } \\
\text { Plan }\end{array}$ & $\begin{array}{l}2018 \text { Master } \\
\text { Plan }\end{array}$ \\
\hline Planning area (ha) & 816 ha & 2378 ha & 12850 ha & 29052 ha & - \\
\hline Projection population of the plan & 75000 & 350000 & 1300000 & 1805000 & 2354753 \\
\hline Population of plannin year* & 58000 & 354758 & 852457 & 742690 & 1315168 \\
\hline Gross density of the plan (p/ha) & 91 & 147 & 101 & 62 & - \\
\hline $\begin{array}{l}\text { Medium density of housing areas } \\
\text { of the plan (p/ha) }\end{array}$ & 140 & 190 & 153 & 105 & - \\
\hline $\begin{array}{l}\text { Development direction of the } \\
\text { plan }\end{array}$ & $\begin{array}{l}\text { Northwest } \\
\text { Southwest }\end{array}$ & $\begin{array}{l}\text { North } \\
\text { East }\end{array}$ & North & $\begin{array}{l}\text { North, South } \\
\text { Northwest } \\
\text { Northeast }\end{array}$ & North \\
\hline $\begin{array}{l}\text { Population in the target of the } \\
\text { plan* }\end{array}$ & $\begin{array}{l}(1965) \\
354758\end{array}$ & $\begin{array}{l}(1985) \\
521287\end{array}$ & $\begin{array}{l}(2000) \\
830796\end{array}$ & $\begin{array}{l}(2020) \\
1359251\end{array}$ & $\begin{array}{l}(2043) \\
-\end{array}$ \\
\hline
\end{tabular}

- The first master plan of Konya was formed in 1946 (Figure 2). The target year of the plan was set as 1965 , and the projection population of the city was estimated to be 75,000 people. The planning area covers approximately 816 ha (Yenice, 2012). The direction of development was mentioned to be the west in the plan. To meet the housing need in Konya owing to the increased population upon the migration from the rural to urban areas, the second plan was prepared as a revision in 1954. The target year of the plan was set as 1965, and the plan covers 912 ha. The direction of development was expanded toward northwest and southwest (Öncü, 2001).

- The third plan was obtained through a competition project in 1966 (Figure 2). The target year of the plan was set as 1985 . The projection population of the city was set as 300-350,000 people, which was believed to potentially reach 480,000 if the investments were complete. The plan covers 
Serdaroğlu Sağ, N. (2021). Assessment of urban development pattern and urban sprawl using Shannon's entropy: A case study of Konya (Turkey). Journal of Human Sciences, 18(2), 252-265. doi:10.14687/jhs.v18i2.6158

an area of approximately 2.380 ha (Yenice, 2012). North and west were selected as the direction of urban development, and the agricultural lands on the south sections of the city and Aslım Batakliğ1 (Aslim Swamp) were considered as natural thresholds in terms of urban development.

- As per the Construction Zoning Law numbered 3194, planning-related authorities were assigned to municipalities during and after 1980s, which caused the emergence of large planning movements in major cities. With the reflection of this process on Konya, the fourth plan of the city was prepared in 1983 (Figure 2). Following the migration from rural to urban areas in Konya, the target year of the plan that was dated 1983 and prepared to meet the housing needs owing to rapid population increase was 2000 . The projection population of the plan was estimated to be $1,300,000$ people. The plan covers an area of approximately 128,600 ha (Yenice, 2012). The city showed a linear development toward north along with the bus terminal, industrial site and illegal housing prevention zones.

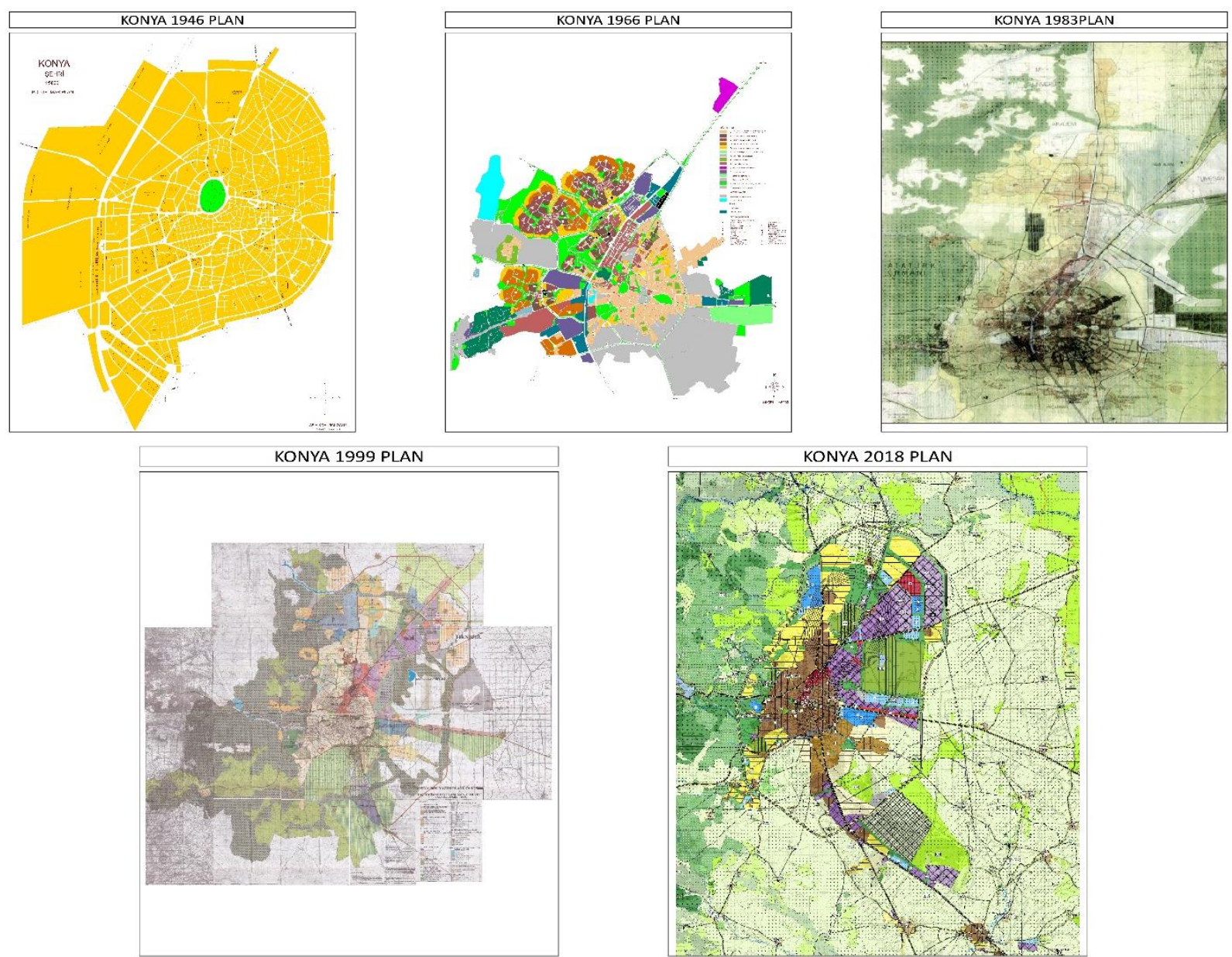

Figure 2. Plans of Konya (Source: Konya Metropolitan Municipality)

- As Konya became a metropolitan city in 1989, building gained momentum and settlements emerged in residential areas, which jeopardized the agricultural areas. The Master Plan scaled $1 / 25,000$, which is the first largest urban plan of Konya, (Figure 2) was prepared in 1999 upon the necessity to supervise the agricultural areas. The target year of the plan was set as 2020 . The projection population of the plan was estimated to be $1,800,000$ people. The plan covers an area of approximately 29,000 ha. North, northwest and south corridor was selected as the development direction of the city (Taşç1, 2000). 
Serdaroğlu Sağ, N. (2021). Assessment of urban development pattern and urban sprawl using Shannon's entropy: A case study of Konya (Turkey). Journal of Human Sciences, 18(2), 252-265. doi:10.14687/jhs.v18i2.6158

- In 2018, Konya Master Plan scaled 1/25,000 was prepared as the last and final plan of the city (Figure 2) (Konya Metropoliten Municipality, 2018). The target year of the plan was set as 2043. The projection population of the plan was estimated to be 2,354,753 people. Through this plan, new urban areas are assigned to the increasing population due to the urban transportation system, and density-related decisions are reorganized. As the direction of development, the city was planned to develop on the north side on the axis of the route to Istanbul.

When the plan proposals are evaluated; Despite the estimation of 1966 plan for 1983 (a population of 350,000 people and a planning area of $2378 \mathrm{ha}$ ), the population reached approximately 520,000 in 1983 and built-up areas covered 9,400 ha based on the calculations performed using satellite images. Despite the estimation of 1983 plan for 2000 (a population of 1,300,000 people and a planning area of 12,850 ha), the population of Konya was 830,796 in 2000 and built-up areas covered approximately 14,900 ha. Despite the estimation of 1999 plan for 2020 (a population of $1,805,000$ people and a planning area of 29,052 ha), the number of people in Konya was 1,359,251 in 2020 and built-up areas covered approximately 32,200 ha. (Table 1, 2). Accordingly, estimations of 1946 and 1966 plans were below the real figures of population increase and urban development. In 1983 and 1999 plans, population increase was under the projection population, and the size of area that underwent building was greater than the planning area, which arose from the addition of plans to development areas rather than the unplanned building. However, the area development reaching beyond the plans' estimations indicates that Konya expanded more compared to previous years.

\subsection{Assessment of urban development pattern}

Konya has 31 districts. The metropolitan area of Konya consists of three central districts: Karatay, Meram and Selçuklu. The urban developments in this section were assessed in regard to these three districts.

Table 2. Population, built-up area, density and relevant increase rates of Konya

\begin{tabular}{|c|c|c|c|c|c|c|}
\hline Year & County & $\begin{array}{l}\text { Population } \\
*\end{array}$ & $\begin{array}{l}\text { Population increase } \\
\text { percentage }(\%)\end{array}$ & $\begin{array}{l}\text { Built-up } \\
\text { area (ha) }\end{array}$ & $\begin{array}{l}\text { Built-up area increase } \\
\text { percentage }(\%)\end{array}$ & $\begin{array}{l}\text { Gross density } \\
\text { (p/ha) }\end{array}$ \\
\hline 1985 & Merkez & 521287 & - & 9431.08 & - & 55 \\
\hline \multirow[t]{4}{*}{1990} & Karatay & 169001 & - & 4398.95 & - & 38 \\
\hline & Meram & 213664 & - & 3174.76 & - & 67 \\
\hline & Selçuklu & 202154 & - & 4458.59 & - & 45 \\
\hline & Total & 584819 & 12 & 12032.3 & 27 & 49 \\
\hline \multirow[t]{4}{*}{2000} & Karatay & 214589 & 26 & 4980.49 & 13 & 43 \\
\hline & Meram & 267878 & 25 & 3406.14 & 7 & 79 \\
\hline & Selçuklu & 348329 & 72 & 6483.04 & 45 & 54 \\
\hline & Total & 830796 & 42 & 14869,67 & 23 & 56 \\
\hline \multirow[t]{4}{*}{2010} & Karatay & 263071 & 22 & 8068.05 & 61 & 33 \\
\hline & Meram & 314421 & 17 & 7113.42 & 108 & 44 \\
\hline & Selçuklu & 508102 & 45 & 9689.39 & 49 & 52 \\
\hline & Total & 1085594 & 30 & 24870.86 & 67 & 44 \\
\hline \multirow[t]{4}{*}{2020} & Karatay & 351422 & 33 & 9746.17 & 20 & 36 \\
\hline & Meram & 344549 & 9 & 10438.54 & 46 & 33 \\
\hline & Selçuklu & 663280 & 30 & 12028.91 & 24 & 55 \\
\hline & Total & 1359251 & 25 & 32213.62 & 29 & 42 \\
\hline
\end{tabular}

*Source: TUIK

The development pattern of the city was discussed in line with these schemas, population, builtup areas and density change rates (Table 2). The schemas regarding the borders of built-up areas specified through the satellite images of Konya from 1985, 1990, 2000, 2010 and 2020 are presented in Figure 3. 
Serdaroğlu Sağ, N. (2021). Assessment of urban development pattern and urban sprawl using Shannon's entropy: A case study of Konya (Turkey). Journal of Human Sciences, 18(2), 252-265. doi:10.14687/jhs.v18i2.6158

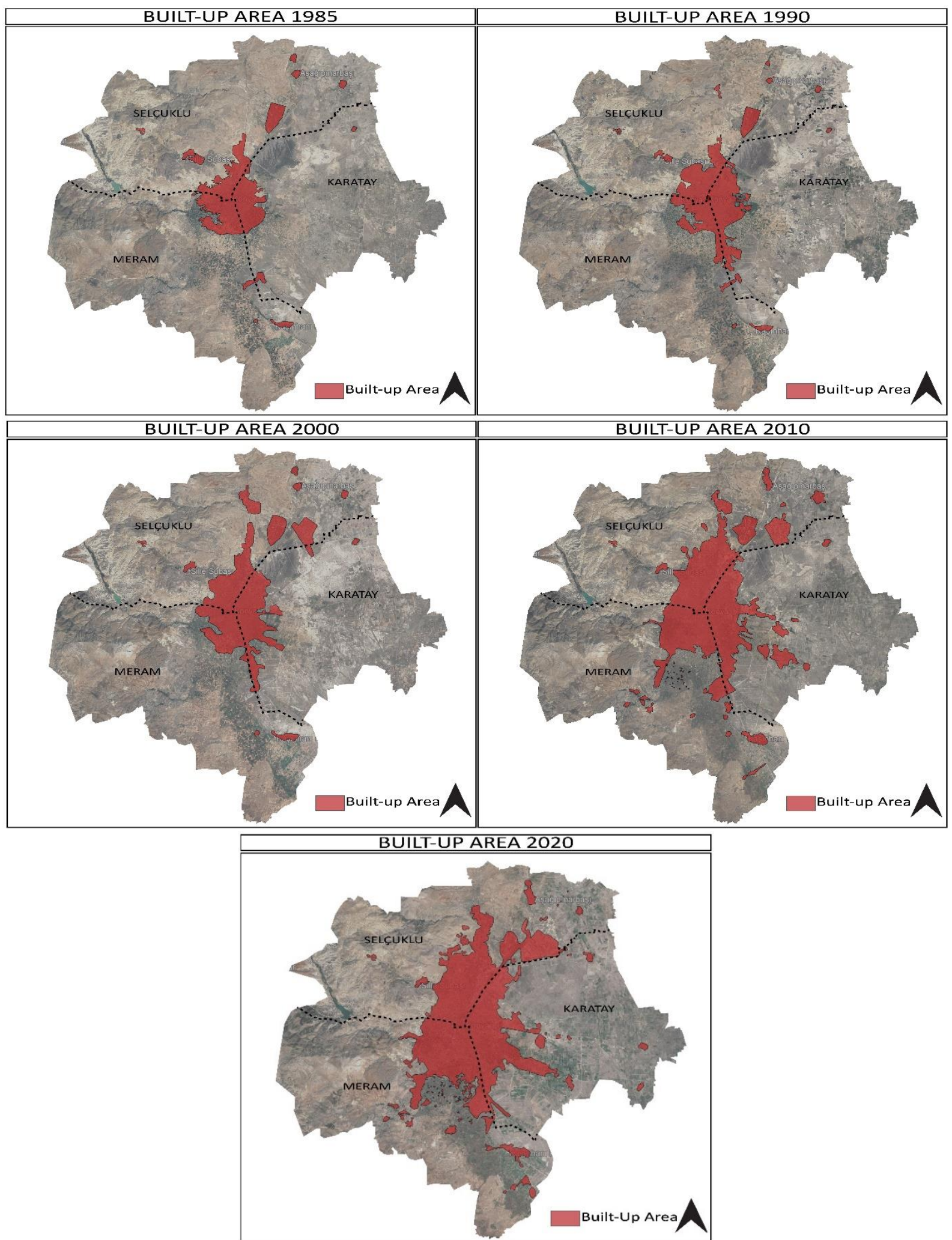

Figure 3. Built-up areas in Karatay, Selçuklu and Meram for 1985, 1990, 2000, 2010 and 2020.

The population of Konya's central district was 521,287 in 1985, reaching 1,359,251 in 2020. The population increased by 160\% between 1985 and 2020, while the rate of built-up areas increased by $241 \%$. Considering the change in the period after the formation of central districts, the population increased by $132 \%$ in the period between 1990 and 2020, and the built-up area increased by 167\%. Accordingly, the rate of increase in the built-up areas in Konya was higher than the population 
Serdaroğlu Sağ, N. (2021). Assessment of urban development pattern and urban sprawl using Shannon's entropy: A case study of Konya (Turkey). Journal of Human Sciences, 18(2), 252-265. doi:10.14687/jhs.v18i2.6158

increase rate. Population density was $55 \mathrm{p} /$ ha in 1985; it was 49, 56, 44 and $42 \mathrm{p} /$ ha in 1990, 2000, 2010 and 2020, respectively. While the urban population increased, population density decreased by years, which was a significant result showing that the urban area gained a more disorganized/scattered structure compared to previous years.

When these three central counties were compared, the rate of increase in the built-up areas between the years of 1990 and 2020 was as follows: Meram (7263.78 ha-228\%), Selçuklu (7570.32ha$169 \%$ ) and Karatay (5347.22 ha-121\%). The order of population increase between the years of 1990 and 2020 was as follows: Selçuklu 228\%, Karatay 107\% and Meram 61\%. When the increase rate of built-up areas and population increase was compared, the change in Meram was approximately four times higher, while Selçuklu grew by one and half time, and the change in Karatay was almost equal. Accordingly, these results are important as they reflect the impacts of settlement-related pressures on spaces in Meram where there are plenty of natural sites. Furthermore, the obligatory amendments arising from the aforenoted impacts included the development of areas with agricultural properties as low-density housing zones with the planned interventions in 2000 and later. In Selçuklu district of Konya, the industrial and housing zones are among the elements guiding urban development. The elements affecting the development in Karatay district included the higher number of public investments such as courthouse, city hospital or university, and the driving impact of these elements on the development. Another important element affecting the urban growth in the city is the transportation-focused investments to light rail system and freeways.

\subsection{Assessment of urban sprawl with Shannon's entropy}

The built-up areas in the study were calculated for each of the central counties in Konya (Karatay, Meram, Selçuklu) and each district was regarded as a separate region. Then, these built-up areas were analyzed considering the total built-up areas. Calculations for Shannon's entropy $[\mathrm{H}=-\Sigma \mathrm{ni}=1$ $\mathrm{Pi} \times \mathrm{Ln}(\mathrm{Pi})]$ are presented in Table 3.

Table 3. Shannon's entropy values of Konya

\begin{tabular}{|c|c|c|c|c|c|c|c|c|}
\hline & 1990 & & & & 2000 & & & \\
\hline Segment & $\begin{array}{l}\text { Built-up area } \\
\text { (ha) }\end{array}$ & $\mathrm{Pi}$ & $\mathrm{Ln}(\mathrm{Pi})$ & $\mathrm{Pi} \times \operatorname{Ln}(\mathrm{Pi})$ & $\begin{array}{l}\text { Built-up area } \\
\text { (ha) }\end{array}$ & $\mathrm{Pi}$ & $\mathrm{Ln}(\mathrm{Pi})$ & $\operatorname{Pi} \times \operatorname{Ln}(\mathrm{Pi})$ \\
\hline Karatay & 4398.95 & 0.3655 & -1.0064 & -0.3678 & 4980.49 & 0.3349 & -1.0939 & -0.3663 \\
\hline Meram & 3174.76 & 0.2638 & -1.3325 & -0.3515 & 3406.14 & 0.2290 & -1.4740 & -0.3375 \\
\hline Selçuklu & 4458.59 & 0.3705 & -0.9929 & -0.3678 & 6483.04 & 0.4359 & -0.8303 & -0.3619 \\
\hline Total & 12032.3 & 1 & -3.3318 & -1.0871 & 14869,67 & 1 & -3.3982 & -1.0657 \\
\hline \multicolumn{4}{|c|}{ H (Shannon's entropy) } & 1.0871 & & & & 1.0657 \\
\hline
\end{tabular}

\begin{tabular}{|c|c|c|c|c|c|c|c|c|}
\hline & 2010 & & & & 2020 & & & \\
\hline Segment & $\begin{array}{l}\text { Built-up area } \\
\text { (ha) }\end{array}$ & $\mathrm{Pi}$ & $\mathrm{Ln}(\mathrm{Pi})$ & $\mathrm{Pi} \times \operatorname{Ln}(\mathrm{Pi})$ & $\begin{array}{l}\text { Built-up area } \\
\text { (ha) }\end{array}$ & $\mathrm{Pi}$ & $\operatorname{Ln}(\mathrm{Pi})$ & $\mathrm{Pi} \times \operatorname{Ln}(\mathrm{Pi})$ \\
\hline Karatay & 8068.05 & 0.3243 & -1.1260 & -0.3651 & 9746.17 & 0.3025 & -1.1956 & -0.3616 \\
\hline Meram & 7113.42 & 0.2860 & -1.2517 & -0.3579 & 10438.54 & 0.3240 & -1.1270 & -0.3651 \\
\hline Selçuklu & 9689.39 & 0.3895 & -0.9428 & -0.3672 & 12028.91 & 0.3734 & -0.9851 & -0.3678 \\
\hline Total & 24870.86 & 1 & -3.3205 & -1.0902 & 32213.62 & 1 & -3.3077 & -1.0945 \\
\hline \multicolumn{4}{|c|}{ H (Shannon's entropy) } & 1.0902 & & & & 1.0945 \\
\hline
\end{tabular}

Shannon's entropy values are between 0 and $\operatorname{Ln}(\mathrm{n})$, with the former indicating a physical development that has concentrated and reached maximum compactness. If the entropy value is higher than $\operatorname{Ln}(\mathrm{n})$ and close to 1, the residential area can be considered to sprawl in an irregular form, and the presence of urban sprawl can be assumed. The entropy value reaching the maximum figure indicates the presence of sprawl in the urban development (Mohammadi et al., 2012; Özkan, 2020; Öztürk, 2017; Sudhira et al., 2004; Yeh \&Li, 2001). 
Shannon's entropy index calculated for Konya for the years 1990, 2000, 2010 and 2020 was $1.0871,1.0657,1.0902$ and 1.0945, respectively. All periods of the index value mentioned above are almost equal to the upper threshold of $\operatorname{Ln}(3)=1.0986$ entropy value. These entropy values indicate that the level of urban sprawl in Konya has increased even more after 2000. Accordingly, the results obtained through Shannon's entropy for Konya indicate that the built-up areas in the city in 2020 were more disorganized compared to the year of 1990, suggesting that the urban development in Konya had a more disorganized structure in time. The physical growth of the city has had an expanding and disorganized manner for the last 30 years.

\section{Discussion}

The results of three analyses performed to examine the urban development and sprawl of Konya indicate that the issue of urban sprawl reached a level requiring external intervention. The change in the planning and borders of built-up areas in Konya (Figure 4) indicates that urban development pattern is planned but has a scattered form.

Planning-related experiences regarding Konya indicate that population growth and urban development did not occur as planned, which arose from the absence of a flexible planning approach that will adapt to the unexpected developments rather than the insufficient properties of planningrelated decisions. Measurements performed with Shannon's entropy quantitatively support that urban development pattern gained a sprawl form. 
Serdaroğlu Sağ, N. (2021). Assessment of urban development pattern and urban sprawl using Shannon's entropy: A case study of Konya (Turkey). Journal of Human Sciences, 18(2), 252-265. doi:10.14687/jhs.v18i2.6158


Figure 4. The change in the planning and borders of built-up areas in Konya 
Serdaroğlu Sağ, N. (2021). Assessment of urban development pattern and urban sprawl using Shannon's entropy: A case study of Konya (Turkey). Journal of Human Sciences, 18(2), 252-265. doi:10.14687/jhs.v18i2.6158

\section{Conclusions and recommendations}

Konya underwent a rapid urban growth in time. This study focused on assessing urban development and sprawl for the period between 1985 and 2020. Results showed that the change in built-up areas triggered urban sprawl in 35 years. Pressures on lands and natural resources increased in line with the population growth. Urban expansion dynamics were effectively and extensively presented using the entropy index approach. Planning approaches in Konya as well as the distribution of the density and decisions related to area use should be re-considered to prevent urban sprawl. Using the spaces in the current built-up areas rather than reserving new areas for urban development will be a significant step in this regard. The probability for the current development to occur should be detailed in planning efforts, and new developments decisions should be made accordingly. Additionally, decisions that will prevent the usage-investment decisions attracting populations from being directed to agricultural regions should be made.

The concept of urban sprawl is a multi-dimensional concept that should be analyzed with different indicators and methods. The analyses performed in this study will guide similar studies in terms of assessing the current development in the process of achieving a more compact and sustainable urban area. This study provides tips for determining and measuring the level of sprawl and understanding the dynamic urban development process better. Through the assessment of current urban development, discussions regarding the problems to be determinated in the following developments and measures to be taken can be performed. Urban sprawl is regarded as one of the potential threats to sustainable development. Therefore, the reasons for having such extensive urban development should be investigated to develop strategies for controlling urban growth and sprawl and ensuring sustainable urban development. Multi-dimentional, flexible and strategic planning policies are needed to prevent urban sprawl. Decisions, developed by planning studies in order to find solutions for the needs of cities and residents, should be able to keep up with changes, have a strategic perspective and adopt sustainable development principles.

\section{References}

Akseki, H., \& Meşhur, M.Ç. (2013). Kentsel yayılma sonucu yapılaşmaya açılan verimli tarım alanları: Konya kenti deneyimleri. Megaron 2013;8(3):165-174. DOI: 10.5505/MEGARON.2013.99609

Alberti, M. (2005). The effects of urban patterns on ecosystem function. International Regional Science Review, 2005, vol. 28, issue 2, 168-192.

Bhatta, B. (2012). Urban growth analysis and remote sensing: a case study of Kolkata, India 19802010. Chapter 2. Dordrecht: Springer, 9-32. https://doi.org/10.1007/978-94-007-4698-5.

Buitelaar, E., \& Leinfelder, H. (2020). Public design of urban sprawl: governments and the extension of the urban fabric in Flanders and the Netherlands, Urban Planning (ISSN: 2183-7635) 2020, Vol. 5, Issue 1, 46-57. DOI: 10.17645/up.v5i1.2669

Burchell, R. W., Listokin, D., \& Galley., C. C. (2000). Smart growth: more than a ghost of urban policy past, less than a bold new horizon. Housing Policy Debate, 11 (4), 821-878.

Burton, E. (2000). The potential of the compact city for promoting social equity. in Achieving Sustainable Urban Form (eds K. Williams, E. Burton and M. Jenks), E \& FN Sp on, London.

Çavuş C. Z., \& Başaran Uysal, A. (2018). Çanakkale'de kentsel gelişme, yayılma ve kırsal alanlarla etkileşim Planlama 2018; (Ek 1):105-117. doi: 10.14744/planlama.2018.85547

EEA Breafing. (2006). EEA Breafing, 2006, USA Environmental Protection Agency. https://www.eea.europa.eu/publications/briefing_2006_1

EEA Report. (2006). Urban sprawl in Europe the ignored challenge. EEA Report No 10/2006 ISSN $1725-9177$.

Ewing, R., Pendall, R., \& Chen, D. (2002). Measuring sprawl and its impact. Smart Growth America, Washington.

Ewing, R.. (1997). Is Los Angeles style sprawl desirable? Journal of the American Planning Association, 63, 1:107-26. 
Serdaroğlu Sağ, N. (2021). Assessment of urban development pattern and urban sprawl using Shannon's entropy: A case study of Konya (Turkey). Journal of Human Sciences, 18(2), 252-265. doi:10.14687/jhs.v18i2.6158

Frenkel, A., \& Ashkenazi, M. (2008). Measuring urban sprawl how can we deal with it. Environment and Planning B, Planning and Design, 35, 56-79.

Galster, G., Hanson, R., Wolman, H., Ratcliffe, M.R., Wolman, H., Coleman, S. \& Freihage, J. (2001). Wrestling sprawl to the ground: defining and measuring an elusive concept. Housing Policy Debate, 12(4), 681-717.

Ghorbani, R. \& Farokhisomeh, M. (2015). An analysis on urban sprawl in the Tabriz metropolitan and its fringe cities. International Journal of Advances in Science Engineering and Technology, ISSN: 23219009 Special Issue-5, Dec.-2015, 82-85.

Glaser, L.E. \& Kahn, M. (2004). Sprawl and urban growth, HIER, Harvard Institute of Economic Research Discussion Paper, Number 2004, Harvard University, Cambridge, Massachusetts.

Hasse, J., E., \& Lathrop, R., G. (2003). Land resource impact indicators of urban sprawl. Journal of Applied Geography, 23, pp.159-175.

Jat, M. K., Garg, P. K. \& Khare, D. (2008). Monitoring and modelling of urban sprawl using remote sensing and GIS techniques, International Journal of Applied Earth Observation and Geoinformation 10(1): 26-43. https://doi.org/10.1016/j.jag.2007.04.002

Karakayac1, Z. \& Karakayac1, Ö. (2019). Determination of urban sprawl effects on farmlands value using GIS. ICONARP International Journal of Architecture \& Planning, 7(2), 513-539.

Konya Chamber of Commerce (Konya Ticaret Odasi). (2020). Konya ekonomi raporu 2019, Anadolu Ofset Konya. 1sbn: 978-605-137-773-5. http://www.kto.org.tr/

Konya Metropolitan Municipality, (2018). 1/25000 ölçekli Konya çevre düzeni planı plan açıklama raporu. Konya: Egeplan - Modül Planlama. https://kentrehberi.konya.bel.tr/\#/rehber/

Konya Metropolitan Municipality

Kumari, K. (2015). Urban sprawl: a case study of Lucknow City. International Journal of Humanities and Social Science Invention, 4 (5): 11-20.

Liu X, et al. (2020). High-spatiotemporal-resolution mapping of global urban change from 1985 to 2015. Nature Sustainability https://doi.org/10.1038/s41893-020-0521-x. https://www.nature.com/articles/s41893-020-0521-x

Mohammadi, J., Zarabi, A., \& Mobaraki, O. (2012). Urban sprawl pattern and effectuve factors on them: the case of Urmia city, Iran. Journal of Urban and Regional Analysis, vol. IV 1, 2012, p. 77-89

OECD. (2018). Rethinking Urban Sprawl: Moving Towards Sustainable Cities, OECD Publishing, Paris.

Öncü, E. (2001). Konya Büyü̈ksehir Alam Kentiçi ve Yakın Çevre Ulaşım Master Planı Çalşsması, Final Raporu, Yüksel Proje-Ulaşım-Art Ortaklı̆̆ı, Ankara.

Özkan, K. (2020). Ekosistem çeşitliliğinin hesaplanmasına yönelik önerilen bir eşitlik. Turkish Journal of Forestry, 21(4): 355- 363. DOI: 10.18182/tjf.766462

Öztürk, D. (2017, a). Shannon entropi ve fraktal analiz ile kentsel yayılmanın incelenmesi: Samsun örneği. TMMOB Harita ve Kadastro Mühendisleri Odas1, 16. Türkiye Harita Bilimsel ve Teknik Kurultay1, 3-6 Mayıs 2017, Ankara.

Öztürk, D., (2017, b). Assessment of urban sprawl using Shannon's entropy and fractal analysis: a case study of Atakum, Ilkadim and Canik (Samsun, Turkey). Journal of Environmental Engineering and Landscape Management. ISSN 1648-6897 / eISSN 1822-4199. Vol. 25(03): 264-276. https://doi.org/10.3846/16486897.2016.1233881

Pendall, R. (1999). Do land use controls cause sprawl? Environment and Planning B:Planning and Design, Volume 26, pp. 555-571.

Resnik, D. B. (2010). Urban sprawl, smart growth, and deliberative democracy. American Journal of Public Health, 100(10), 1852-1856.

Sarvestani M.S., Ibrahim L. A., \& Kanaroglou P. (2011). Three decades of urban growth in the city of Shiraz, Iran: A remote sensing and geographic information systems application. Cities, 28(4), 320-329. doi:10.1016/j.cities.2011.03.002.

Serdaroğlu Sağ, N. (2011). Dönüşüme bağlı kentsel gelişmenin yönetilmesinde bir araç olarak akıllı büyüme; Konya kenti örneği. Doktora Tezi. Selçuk Üniversitesi, Fen Bilimleri Enstitüsü, Konya. 
Serdaroğlu Sağ, N. (2021). Assessment of urban development pattern and urban sprawl using Shannon's entropy: A case study of Konya (Turkey). Journal of Human Sciences, 18(2), 252-265. doi:10.14687/jhs.v18i2.6158

Shannon, C.E. (1948). A mathematical theory of communication. The Bell System Technical Journal, 27(3): 379-423.

Shenbagaraj, N., Kumar, M. N., \& Stalin, J. L. (2019). Assessment of urban growth using Shannon's Entropy Index: A case study of Chennai, Detroit of India. Journal of Applied and Natural Science, 11(2): 281- 284. https:// doi.org/10.31018/jans.v11i2.2037

Sierra Club, 1998. The dark side of the American Dream: The costs and consequences of suburban sprawl. (http://www. sierraclub.org/sprawl/report98/)

Steurer, M. \& Bayr, C. (2020). Measuring urban sprawl using land use data https://doi.org/10.1016/j.landusepol.2020.104799

Sudhira, H. S., Ramachandra, T. V., \& Jagadish, K. S. (2004). Urban sprawl: metrics, dynamics and modelling using GIS. International Journal of Applied Earth Observation and Geoinformation, 5(1): 2939. https://doi.org/10.1016/j.jag.2003.08.002

Sun, H., Forsythe, W., \& Waters, N. (2007). Modeling urban land use change and urban sprawl: Calgary, Alberta, Canada. Networks and Spatial Economics 7(4): 353-376. https://doi.org/10.1007/s11067-007-9030-y

Taşçı, Y. (2000). Konplan 2020 Çevre Düzeni Planı Araştırma Raporu.

Terzi, F., \& Bölen, F. (2010). Measuring urban fringing in Istanbul. A|Z ITU Journal of the Faculty of Architecture. 9(2), 166-178.

Torrens, P. M. \& Alberti, M. (2000). Measuring sprawl. CASA Working Papers 27. Centre for Advanced Spatial Analysis (UCL), London.

TUIK-Türkiye İstatistik Kurumu (http://www.tuik.gov.tr)

UN United Nations- (2019). World Urbanization Prospects 2018 : Highlight. New York: United Nations, Department of Economic and Social Affairs. https://population.un.org/wup/Publications/Files/WUP2018-Highlights.pdf

WEB1 - https://cevreselgostergeler.csb.gov.tr/kentsel---kirsal-nufus-orani-i-85670

WEB2 - https://cevreselgostergeler.csb.gov.tr/kentsel---kirsal-nufus-orani-i-85670\#_ednref1

WEB3 - https://businessht.bloomberght.com/piyasalar/haber/1486626-turkiye-30-yilda-40milyon-dekar-tarim-arazisi

kaybetti\#: :text=Yap $\% C 4 \% B 11 a \% C 5 \% 9 F m a n \% C 4 \% B 1 n \% 20$ artmas $\% C 4 \% B 1 \% 20 i l e \% 20$ so

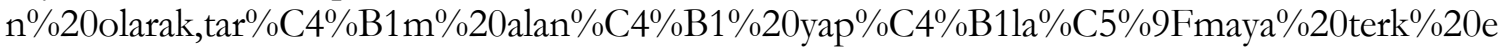
dildi.\&text $=$ Ayr $\%$ C4 $\%$ B1 ca $\% 20 \mathrm{i} \% \mathrm{C} 5 \% 9$ Flenmese $\% 20 \mathrm{de} \% 20 \operatorname{tar} \% \mathrm{C} 4 \% \mathrm{~B} 1 \mathrm{~m} \% 20 \mathrm{alan} \% \mathrm{C} 4 \% \mathrm{~B}$ 1,de $\% 20$ her $\% 20$ ge $\%$ C $3 \%$ A 7 en $\% 20 y \% C 4 \% B 11 \% 20$ azal $\%$ C $4 \%$ B1yor

WEB4 http://www.kto.org.tr/tarim449s.htm\#: :text=Konya $\% 20 \mathrm{ge} \% \mathrm{C} 3 \% \mathrm{~A} 7 \mathrm{ti} \% \mathrm{C} 4 \% 9$ Fimiz $\% 20 \mathrm{y} \% \mathrm{C} 4 \% \mathrm{~B} 1 \mathrm{la} \% 20 \mathrm{~g} \% \mathrm{C} 3 \% \mathrm{~B} 6 \mathrm{re}$ $\% 20$ toplam,8\%2C29'unu $\% 20$ olu $\%$ C5\%9Fturmaktad $\% C 4 \% B 1$ r

Yavuz, F. (2021). Urban sprawl: An empirical analysis for Konya Province Turkey. ITU $A \mid Z$. Vol 18 No 1, March 2021, 79-97.

Yeh, A. G. O., \& Li, X. (2001). Measurement and monitoring of urban sprawl in a rapidly growing region using entropy. Photogrammetric Engineering \& Remote Sensing 67(1): 83-90.

Yenice, M.S. (2012). Konya kentinin planlama tarihi ve mekânsal gelişimi. Erciyes Üniversitesi Fen Bilimleri Enstitüsü Dergisi, 28(4), 343-350. 